\title{
Busi Beáta
}

\section{Online lehetőségek német nyelvtanuláshoz}

\author{
Busi, Beáta \\ Online facilities for German language learning
}

Összefoglaló

A felgyorsult globalizált világ minden területen igyekszik felhasználni a tudomány és technikai fejlödés vívmányait, hogy azzal könnyebbé, szabadabbá tegye az ember életét. Így vonult be az elearning is a tanulás-tanitás folyamatába, azon belül a nyelvtanitás megkönnyitésére is. Lehetövé teszi, hogy a tanuló maga ossza be idejét, ezzel anyagi megtakarítást is realizál (útiköltség, kötött időpont). Nem feltétlenül szükséges a tanár jelenléte, az interneten a megoldott feladatok önállóan ellenőrizhetök. Ideális módszer az élethosszig tartó tanuláshoz. A Bethlen István Szakkollégium keretein belül indított „Online lehetöségek német nyelvtanuláshoz” címú szeminárium a nyelvtanulás hatékonyságának javításához, élvezetesebbé tételéhez kivánt segítséget nyújtani a hallgatóknak. A szemináriumhoz füződő oktatási-kutatási munkát az alábbiakban foglalom össze.

Kulcsszavak: e-learning, élethosszig tartó tanulás, e-tanulási módok, online nyelvtanulási eszközök, hasznos weboldalak

\begin{abstract}
Our fast-moving, globalised society is trying to use the achievements of scientific and technological developments in all fields of life in order to make people's lives easier and provide them with more flexibility. This is why e-learning has also entered the teaching-learning process, foreign language teaching included. By using this method, students can manage their own time or even save money (no travelling costs, fixed times). The teacher's presence is not absolutely necessary as students can check the exercises and tasks performed through the internet. This is the ideal method for lifelong learning. The seminar called 'Online facilities in German language learning' started at Bethlen István College for Advanced Studies is aimed at improving the efficiency of language learning and making it more enjoyable for students. A summary of the teaching and research work related to the seminar is given below.
\end{abstract}

Key words: e-learning, lifelong learning, e-learning methods, online language learning tools, useful websites

\section{BEVEZETÉS}

A nyelvtanulást a modern technika felhasználásával érdekessé, szórakoztatóvá igyekszünk tenni úgy, hogy a kiscsoportos képzés keretében eredményessé és hasznossá, befektetéssé váljon a résztvevők számára a ráfordított idő. Erre elsősorban az internet felhasználásával van mód, ami a nyelv egyéni elsajátításában is nagy segítség, a nyelvtanulási igény motiválásában is ösztönöz. Hozzájárul egy emberöltőn át való könnyed nyelvtanulás sikeréhez, ami a sikeres megértésben és kommunikációban csúcsosodik ki.

\section{AZ E-LEARNING?}

Az e-learning (e-tanulás) gyökerei már a rádió elterjedésével megjelentek, amikor a gyerekek a rádióban feladott leckét oldották meg, majd az iskola TV és az egyéb technikai eszközök 
(magnó, videó, számítógép) emelték, tökéletesítették a mai szintre. Ma már nem csak iskolában vagy otthon, de akár sétálás közben megfelelő eszköz (táblagép, okostelefon) segítségével is lehet tanulni. A mai fiatalok fogékonyak a technikai eszközök használatára, ők beleszülettek a számítógépek korába, ezért szívesen alkalmazzák azokat.

Jellemzőik:

- nyitottak új dolgok elsajátítására,

- praktikus, gyakorlatias szemléletúek,

- bátran kezdeményeznek,

- bíznak saját képességeikben,

- az egyén szabadságát nagyra értékelik,

- a technikai változásokat gyorsan elsajátítják,

- az internet segítségével a világ bármely pontján elvégzik feladataikat, létrehozzák virtuális közösségeiket.

Az e-learning olyan tanulási módok gyűjtőfogalma, amelyekben a tanulás folyamatát digitális médiák támogatják. Az elektronikus alapon szervezett digitális tanulási médiák a tanulóknak a tananyagot multimediálisan prezentálják és lehetővé teszik számukra azok interaktív feldolgozását, legyenek azok előre megadott instrukciós struktúrákban vagy hálózati struktúrákban az önállóan irányított tanulás számára. A virtuális tantermek az interneten, amelyekben a digitális tanulási médiákat kínálják és feldolgozzák, a valós tantermekhez hasonlóak, amelyekbe csak online lehet belépni, más tanulókkal és az oktatókkal aszinkron vagy szinkron lehet kommunikálni és kooperatívan, együttmúködőn lehet tanulni. (Arnold, 2011: 18).

A szinkron módszerben a tanár és a tanuló azonos időben, de elkülönült térben dolgozik (tanít ill. tanul), ilyen pl. a „virtuális osztályterem"-ben folyó munka, amikor a tanár nagy távolságból oktat. Az aszinkron módszernél a tér és az idő is más, a tanuló a neki megfelelő időben egyénileg tanulja meg a tanár által korábban elkészített és a szerverre tett anyagot. A kooperatív tanulási módszernél a tanulók egymással kapcsolatban vannak.
Sok nyelvtanár már alkalmaz a nyelvoktatás során egyes e-learning elemeket. Például, ha kiscsoportok azt a feladatot kapják, hogy kutassanak az interneten, hogy mely látnivalók érdekesek a fiatalok számára Európa nagyvárosaiban és eredményeiket a blogjukban mutassák be. A virtuális tantermek ebben az esetben az adott város weboldala és a blog.

E-learning elemet alkalmaznak a tanárok akkor is, ha a tanulókkal interaktív online-feladatokat dolgoztatnak fel a tanult tankönyvhöz kapcsolódóan vagy tanulószoftvereket alkalmaznak. Ebben az oktatást kísérő elearning szcenáriókban általában nem online, hanem szemtől szembe kommunikálnak.

A komplexebb e-learning forgatókönyvekben az internetes tanulóplattformokon az információfelvétel és -feldolgozás mellett kommunikatív és/vagy kooperatív feladatokat is kaphatnak, amelyek sokrétű interakciót követelnek meg a tanulók és a tananyag között, maguk a tanulók között, valamint a tanulók és tanárok között. A digitális médiáknak (az otthoni asztali számítógéptől kezdve a mobil eszközökig, mint okostelefonok vagy táblagépek) az a funkciójuk, hogy ezt az online tanulást múszaki szinten lehetővé tegyék. Az alkalmazott web-oldalaknak és szoftvereknek valamint a feladatmegadásnak az a funkciója, hogy az interaktív tanulást didaktikai szinten bevezessék és támogassák. Úgy, ahogy a tábla, a kréta és a tankönyv önmagukban még nem eredményeznek jó tanítást, éppúgy nem garantálnak puszta jelenlétükkel tanulási sikert, fejlődést önmagukban a számítógép, az (oktató)szoftver és a weboldalak sem.

$\mathrm{Az}$ e-learning olyan csatornákat nyit meg, amelyek a tananyaggal való önállóan szervezett megismerkedését/szembesülést támogatják.

Az e-learning tanulás/tanítás során hiányzik: a mimika, gesztikuláció, érintés, mozgás.

Az online-tanulási formátum erőssége viszont, hogy a tanulók meghatározhatják, hogy milyen csatornán keresztül, mely időintervallumban és mely helyen dolgozzák fel, sajátítják el legkönnyebben, leggyorsabban a tananyagot. 


\section{E-LEARNING-MÓDOK}

A közösségi hálózatokat (Facebook, Twitter, Google+, MyVIP, Iwiw, Linkedln) a legtöbb fiatal és fiatal felnőtt használja. Chatelnek, YouTubet, Wikipédiát használnak, online-játékokat játszanak, blogot írnak. Ennek az informális internethasználatnak a célja a barátokkal és idegenekkel folytatott individuális kommunikáció, az önállóan létrehozott vagy talált fájlok megosztása és egymás közti cseréje.

A formális e-learning kínálatokban leggyakrabban olyan anyagokat kínálnak és használnak, amelyek az oktatást segítik. Gyakran interaktív online-gyakorlatokat és az öntesztelés lehetőségeit alkalmazzák.

1. e-learning-mód: oktatást kísérő anyagok és interakció szoftver segítségével

$\mathrm{Az}$ idegennyelv oktatásban a négy készség (hallás utáni értés, olvasásértés, beszéd és íráskészség) fejlesztése, ezek egymással történő kombinálása és a struktúrák elsajátítása zajlik. A négy nyelvi kompetencia támogatására a legtöbb tankönyvkiadó ma már díjtalanul kínál a tankönyveihez interaktív online-gyakorlatokat és kiegészítő szövegeket a hallás- és olvasásértés fejlesztésére. Az, hogy a tanuló önállóan határozhatja meg, hogy milyen gyakran hallgat meg egy szöveget és ezáltal a megértést nyugodtan gyakorolhatja, egy nagy plusz, amely a sokrétű internetes audio- és videókínálatnak köszönhetően egyre érdekesebbé válik.

A személyes oktatásban azután mozgásba hozható a kiegészítő online-gyakorlat során aktivált pangó tudás pl. továbbfejlesztő feladatokkal, mint egy szerepjáték, ahol az olvasott vagy hallott szöveg reflexiójáról vagy megvitatásáról van szó.

2. e-learning-mód: kommunikatív feladatok $\mathrm{Az}$ idegen nyelvet tanuló észrevétlenül fejleszti nyelvtudását akkor is, ha idegen nyelven kommunikál internetes fórumokon, chatel.
A fiatalok gyakran szívesebben is nyilatkoznak meg kötetlen formában az interneten, mint a formális tanulási körülmények között.

3. e-learning-mód: kooperatív feladatok

A tanulók online-csoportmunka keretén belül, egymással együttmúködve a neten oldanak meg feladatokat, amelyek bevezetéséül szolgálhatnak a személyes oktatásban alkalmazott csoportmunkának is.

\section{ONLINE NYELVTANULÁSI ESZKÖZÖK}

1. Szókártyák, amelyek lehetővé teszik a tanulónak ill., a tanárnak, hogy saját tanulókártya szetteket állítson össze, ezek segítségével játékosan tanulja ill., tanítsa a szókincset, esetleg új szavakon túl tartalmakat (definíció, felsorolások, stb.) sajátítson el. A szavak képekkel vizualizálhatók, hangaláfestéssel könnyíthető a memorizálás.

Gyakorolhat a diák a személyreszabottan kialakított szókártyáival a számítógép mellett, de a kártyák ki is nyomtathatók, ill. ezek az alkalmazások általában okostelefonos applikációkkal is letölthetők, hogy útközben, buszra várakozva, vonaton, bárhol használhassuk szókártyáinkat. Jó példák erre a következő oldalak:

- Memocard (http://www.memocard.de/)

- card2brain (https://card2brain.ch/)

- Cobocard (http://www.cobocards.com/de/)

- Quizlet (https://quizlet.com/)

- Szótanulóapplikációk (a Goethe Intézet is kínál ilyeneket különböző nyelvekhez https://www.goethe.de)

2. kommunikatív eszközök

Fórumok, chatszobák, skype különösen alkalmasak idegen nyelvi kommunikációra, mert rajtuk keresztül a tanulók a beszélt nyelvet (szóban vagy írásban beszélt) oktatáson kívül is begyakorolhatják ( $p l$. iskolákat vagy országokat átfogó projektekben). A fórumokon, a chatelés során, az e-mailekben is a beszélt nyelvet alkalmazzuk. 


\section{1. ábra. Szókártyák}

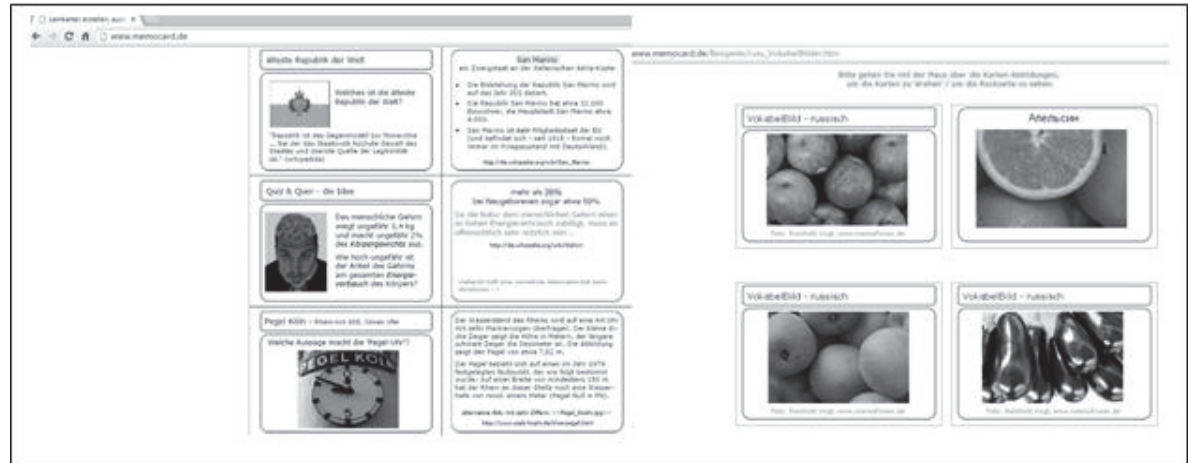

Forrás: http://www.memocard.de/, 2015

$\mathrm{Az}$ interneten egy sor lehetőség van, hogy ezeket a kommunikatív eszközöket használjuk. A fórumoknak megvan az a nagy előnye, hogy a tanulók minden nyomás nélkül fogalmazhatják meg hozzászólásaikat. Olyan segédeszközök, mint a szótár, a nyelvtan vagy a tankönyv használata itt egyenesen elvárt. A chatelés viszont nyelvi biztonságot és gyors gépelést igényel. Ha a nyelvi eszközök, a szókincs, a struktúrák kellőképpen elő vannak készítve, akkor már kezdő szinteken is alkalmazható. Skype-on, a virtuális osztályteremben a tanórától függetlenül is lehet gyakorolni a beszédet, akár a tanárral külön egyeztetett időpontban.

\section{3. kooperatív eszközök}

Olyan virtuális segédeszközök, amelyek nagy távolságból is lehetővé teszik és megkönnyítik az együttdolgozást. A dokumentumok emailekkel történő oda-visszaküldésének megvannak a buktatói, gyakran az együttmúködő felek már nem tudják, melyik volt a végső verzió, némelyik a spam-mappában landol, vagy teljesen elvész. Éppen a projektfeladatoknál, amelyeket házi feladatként vagy az online-szakaszban kell feldolgozni, nagy segítség az olyan online eszköz, amely támogatja az együttmúködést. Az első olyan online eszköz, mely a szövegek közös létrehozását, feldolgozását tette lehetővé a wikipédia volt.
A közös szöveget itt nem merevlemezen, hanem az interneten hozzák létre és a verzióellenőrzésből mindig látható, hogy ki mit változtatott.

Ma már ez az oldal standard és jól alkalmazható szövegek aszinkron feldolgozására. A wikipédiához hasonlóan újabb online eszközök, mint az etherpad (https://etherpad.mozilla.org/), a dropbox (https://www.dropbox.com/), az ubuntu one (https://login.ubuntu.com) a dokumen-tumok közös feldolgozását teszik lehetővé.

\section{4. játékon alapuló tanulás}

Régóta tudjuk, hogy a játék sikeresebbé, élvezetesebbé teszi a tanulást, a digitális médiák pedig megnövelik annak esélyét, hogy ilyen (nyelvi) játékokat készítsünk és a számítógépen vagy akár útközben (okostelefon, táblagép) használjunk.

A nyelvoktató weboldalak kínálatában a már hagyományosnak számító feleletválasztós feladatok mellett egy sor virtuális tanulójátékot is találunk, mint pl. memóriakártya, mondatpuzzle, szókereső játékok, keresztrejtvények, akasztófa-szókitaláló játékok, stb. Léteznek olyan weboldalak, amelyek lehetőséget kínálnak a tanulóknak saját fotóikból képregény készítésére, melyek segítségével a nyelvórákon játékos módon lehet idegen nyelvű dialógusokat, képtörténeteket kreálni. (http://comiclife.com/, 
5. „,komoly” játékok

Az ún. komoly játékok olyan digitális játékok, amelyek nem elsősorban vagy nem kizárólag a szórakozást szolgálják, bár kötelezően tartalmaznak szórakoztató elemeket. Információt és képzést kell közvetíteniük szórakoztatva.

A tanulási tartalmakat különálló, egymással azonban narratívan összefüggő jelenetekben kínálják, a jelenetváltás pedig csak akkor történik meg, ha a felhasználó az adott

\section{.ONLINE NÉMET NYELVGYAKORLÁS A BETHLEN ISTVÁN SZAKKOLLÉGIUMBAN}

$\mathrm{Az}$ e-learninggel kapcsolatos előbbi szempontokat figyelembe véve és azokat a gyakorlatban alkalmazva a Szolnoki Főiskolán a 2014-15. tanév II. félévében bevezetésre került egy tanulócsoportban az „Online lehetőségek német nyelvtanuláshoz" című tantárgy, amelynek keretében a hagyományos papír alapú nyelvtanulás kiegészítésére ezekkel a lehetőségekkel ismerkedtek a hallgatók.

A szemináriumi munka folyamán a csoportban a következő kérdéseket tettem fel az online nyelvtanulással kapcsolatban: feladatokat sikeresen megoldotta. Döntő jelentőségű a virtuális játék lehető legvalóságosabb kialakítása és egy optimális érzékelés létrehozása, úgy, hogy a tanulók minél erősebben érezzék jelenlétüket a virtuális világban. (Schlemminger, G., 2012).

Francia és német kutatócsoportok az iskolai idegennyelv-oktatás keretei között alkalmazható 3-D-s játékot is kifejlesztettek már (EVEIL-3D - http://www.eveil-3d.eu/index.php)

\section{HÁNY ÉVE TANULA A NÉMET NYELVET?}

A válaszokból kiderül, hogy minden hallgató legalább 5 éve tanul németül. (5-8 év: $33 \%$, 910 év: $67 \%)$

\section{MILYEN ONLINE NYELVTANULÁSI LEHETŐSÉGEKET PRÓBÁLT?}

A táblázat azt mutatja, hogy az internetet a hallgatók leginkább kapcsolattartásra használják, de a főiskolai tanulmányok során többszörösen megnőtt az online nyelvtanulási, nyelvgyakorlási lehetőségek iránti érdeklődés.

1. táblázat. Milyen online nyelvtanulási lehetőségeket próbált?

\begin{tabular}{|l|c|c|}
\hline & $\begin{array}{c}\text { a főiskola előtti } \\
\text { német } \\
\text { nyelvtanulás } \\
\text { során }\end{array}$ & $\begin{array}{c}\text { a főiskolai } \\
\text { német } \\
\text { nyelvtanulás } \\
\text { során }\end{array}$ \\
\hline $\begin{array}{l}\text { Némettanulással összefüggő } \\
\text { internetes kapcsolattartás } \\
\text { (némettanárral, diákokkal) }\end{array}$ & $25 \%$ & $90 \%$ \\
\hline $\begin{array}{l}\text { Német nyelvoktató } \\
\text { weboldalakon kijelölt feladatok } \\
\text { megoldása }\end{array}$ & $18 \%$ & $85 \%$ \\
\hline $\begin{array}{l}\text { Nyelvgyakorlási lehetőség önálló } \\
\text { keresése }\end{array}$ & $33 \%$ & $60 \%$ \\
\hline $\begin{array}{l}\text { Házi feladathoz német oldalak } \\
\text { böngészése }\end{array}$ & $17 \%$ & $65 \%$ \\
\hline $\begin{array}{l}\text { Német nyelvú hanganyagok } \\
\text { letöltése, meghallgatása }\end{array}$ & $35 \%$ & $55 \%$ \\
\hline
\end{tabular}




\section{MILYEN HÁZI FELADATOT CSINÁL SZÍVESEBBEN?}

3. ábra. Milyen házi feladatot csinál szívesebben?

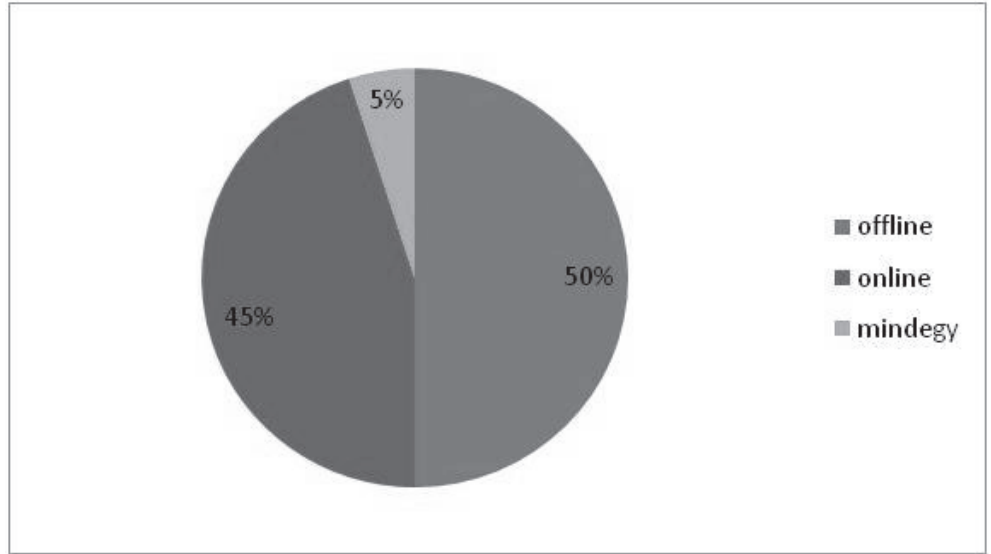

Forrás: saját kutatás, 2015

A fenti kérdésre adott válaszok majdnem egyenlő arányban oszlanak meg az offline (kurzuskönyvből, munkafüzetből papíralapú) (50 \%) és online (45 \%) feladatok között.

\section{MILYEN ARÁNYÚ ONLINE HÁZI FELADATNAK ÖRÜLNE A KÖVETKEZÖKBEN?}

4. ábra. Online házi feladatok aránya

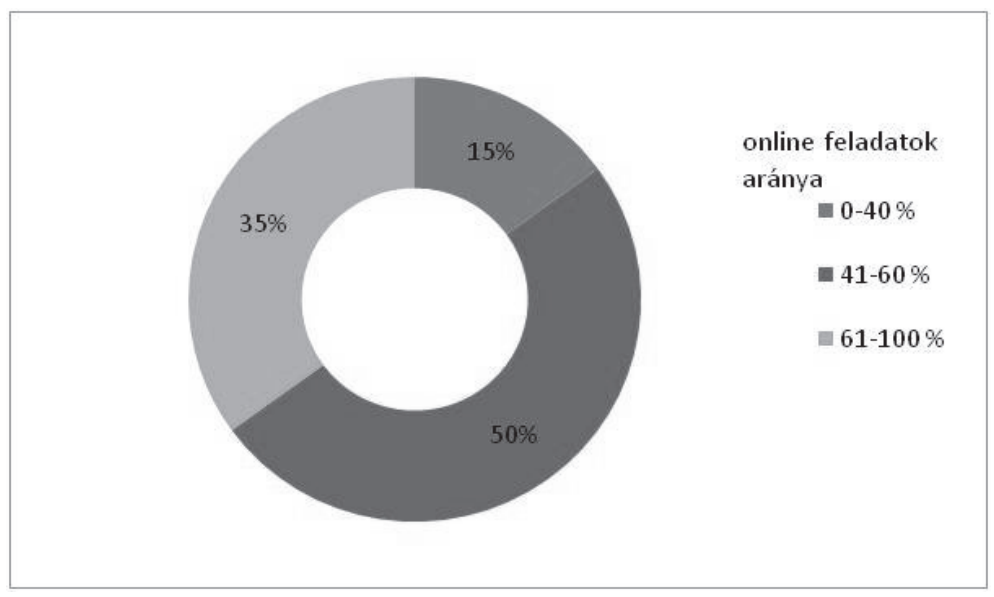

Forrás: saját kutatás, 2015 A hallgatók fele a házi feladatokat 41-60 \%-ban oldaná meg szívesen online, 35 \% akár ennél több online feladatnak is örülne, ami szintén igazolja az e-learning jogosultságát az idegennyelvoktatásban. 


\section{ÖN SZERINT MIRE ALKALMAS LEGINKÁBB AZ ONLINE NYELVGYAKORLÁS?}

\section{5. ábra. Ön szerint mire alkalmas leginkább az online nyelvgyakorlás?}

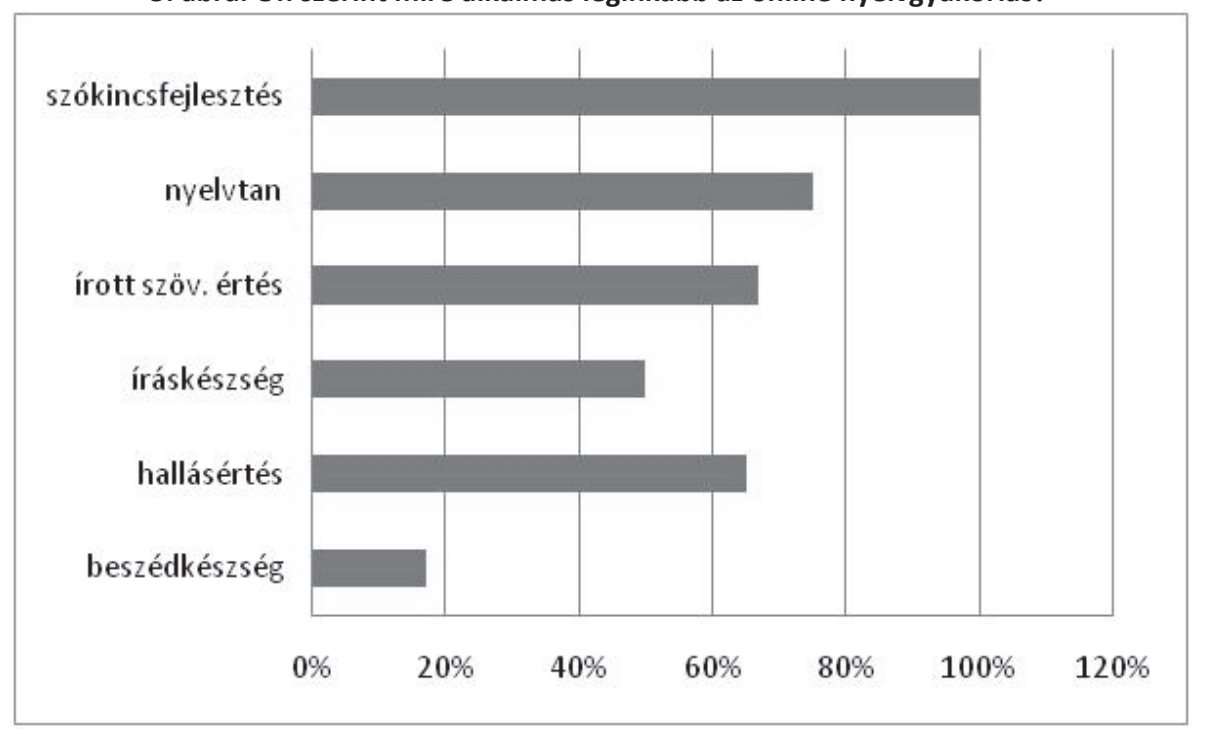

Forrás: saját kutatás, 2015

A kérdésre adott válaszokból kiderül, hogy a hallgatók a nyelvtanulás során az online feladatok közül leghasznosabbnak a szókincsfejlesztést tartják. Véleményük szerint könnyebben rögzülnek a szavak és nem fáradnak úgy, mint a hagyományos tanulási módnál. A nyelvtani gyakorló feladatok mellett népszerűek az írott és hallott szövegértési gyakorlatok is, ugyanis nem anyanyelvi környezetben online juthatnak legkönnyebben ilyen jellegú autentikus tananyaghoz.

A hallgatók a következő témakörökhöz kaptak online gyakorlólehetőségeket:

- Szintfelmérés online

- Nyelvtan online

- Szókincsfejlesztés online (hasznos szófordulatok, kifejezések, szólások, szleng)

- Szakszókincs-fejlesztés online (témák: szociális piacgazdaság, gazdasági körforgás, a piac és az ár, verseny, marketing, vállalati formák, pénz és bank, fizetési módok, fogyasztás, Európai Unió, turizmus, munkahely)

- Olvasott szövegértési készség fejlesztése online

- Gazdasági hírek online

- Hallásértés fejlesztése online

- Üzleti írásbeli és szóbeli kommunikáció online (munkábaállás, pályázás, állásinterjú)

- Nyelvvizsga-felkészülés online

- Egyéb hasznos linkek (online-szótárak, enciklopédiák, rövidítések)

A félév során feldolgozott weboldalak: www.klett.de/einstufungstest http://www.hueber.de/einstufungstests/theme n aktuell/

http://deutsch.lingolia.com/de/

http://www.udoklinger.de/

http://www.schubert-

verlag.de/aufgaben/index.htm http://www.land-der-woerter.de/index.html http://www.graf-gutfreund.at/ 
http://www.iik.de

http://www.mein-

deutschbuch.de/lernen.php?menu id=3

http://www.dw.de/deutsch-lernen/top-

thema/s-8031

http://ueben.klett.de/code/q34zm8

http://www.bpb.de/internationales/europa/eu

ropaeische-union/43106/quiz

http://www.tourneu.eu/

http://eignungstest. plakos.de/?gclid=CIXb-

5nM-bOCFUTMtAodUhMAVQ

http://www.wirtschaftsdeutsch.de/lehrmaterial

ien/telefon3.html

http://www.slowgerman.com/

http://www.osd.at/

http://web.telc.net/unser-angebot/deutsch/

http://www.hueber.de/woerterbuch/online/

http://www.abkuerzungen.de/main.php?langu

age

http://www.dw-world.de

http://www.spiegel.de/

\author{
http://www.focus.de/ \\ http://faz.net/ \\ http://ard.de/ \\ http://zdf.de/
}

A kiscsoportos oktatás keretében a tanulók gyakorlatot szereztek tanulási módszerükhöz internetes oldalakon fellelhető feladatok megoldásával. A szemináriumokon a hallgatók sokféle hasznos linket ismertek meg, próbáltak ki a tematikában megjelölt nyelvi készségek fejlesztéséhez, és igényeiknek megfelelő tanulási módszer alkalmazásával kaptak elegendő segítséget az önálló folyamatos tanuláshoz.

A kipróbált weboldalak többsége különböző nyelvi szinteken (A1-C2), több, mind általános, mind szaknyelvi témában, nem csak egy nyelvi készség fejlesztésére kínál lehetőséget. Jól példázzák ezt a következő online gyakorló oldalak:

\section{6. ábra. német online feladat 1 .}

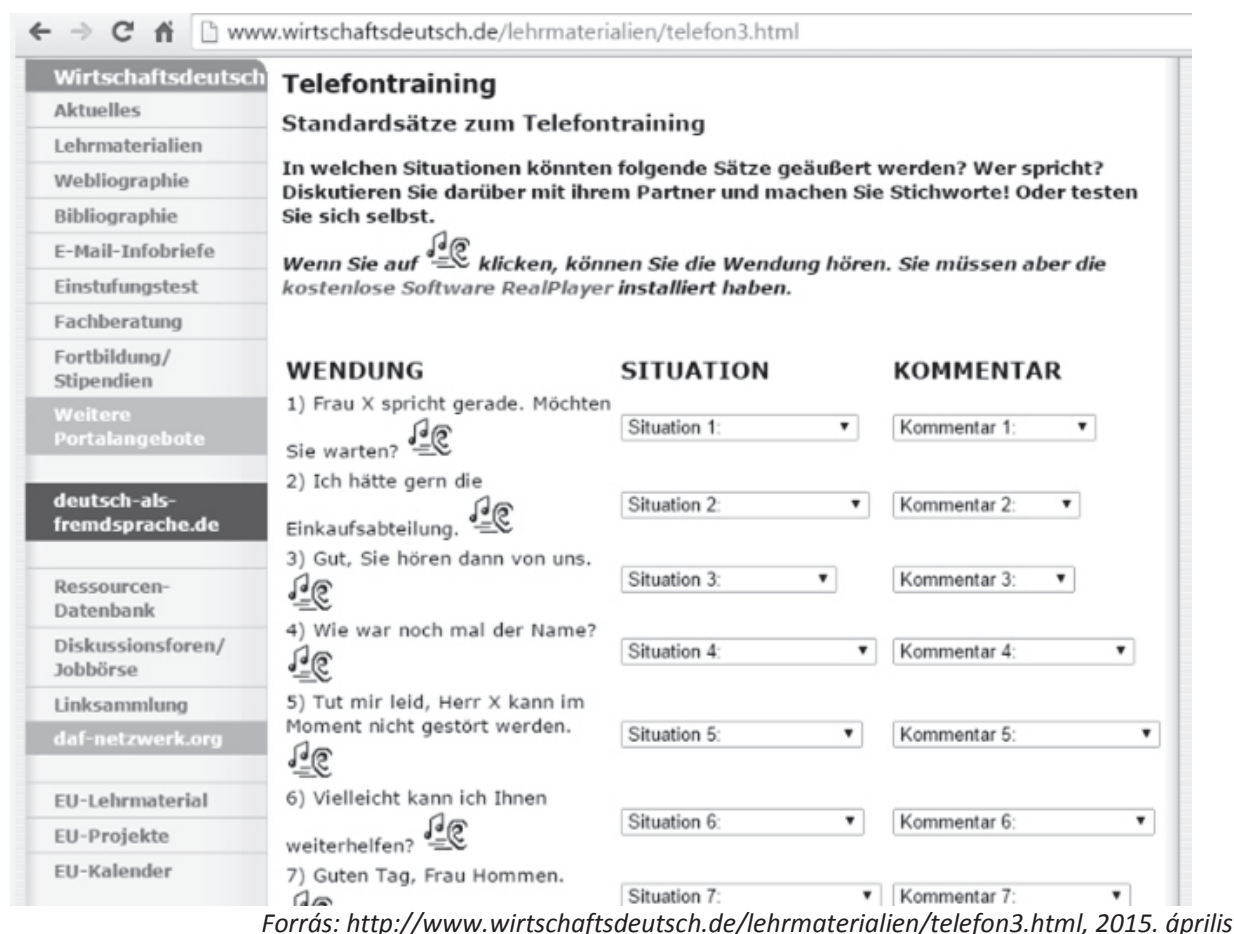


7. ábra. német online feladat 2.

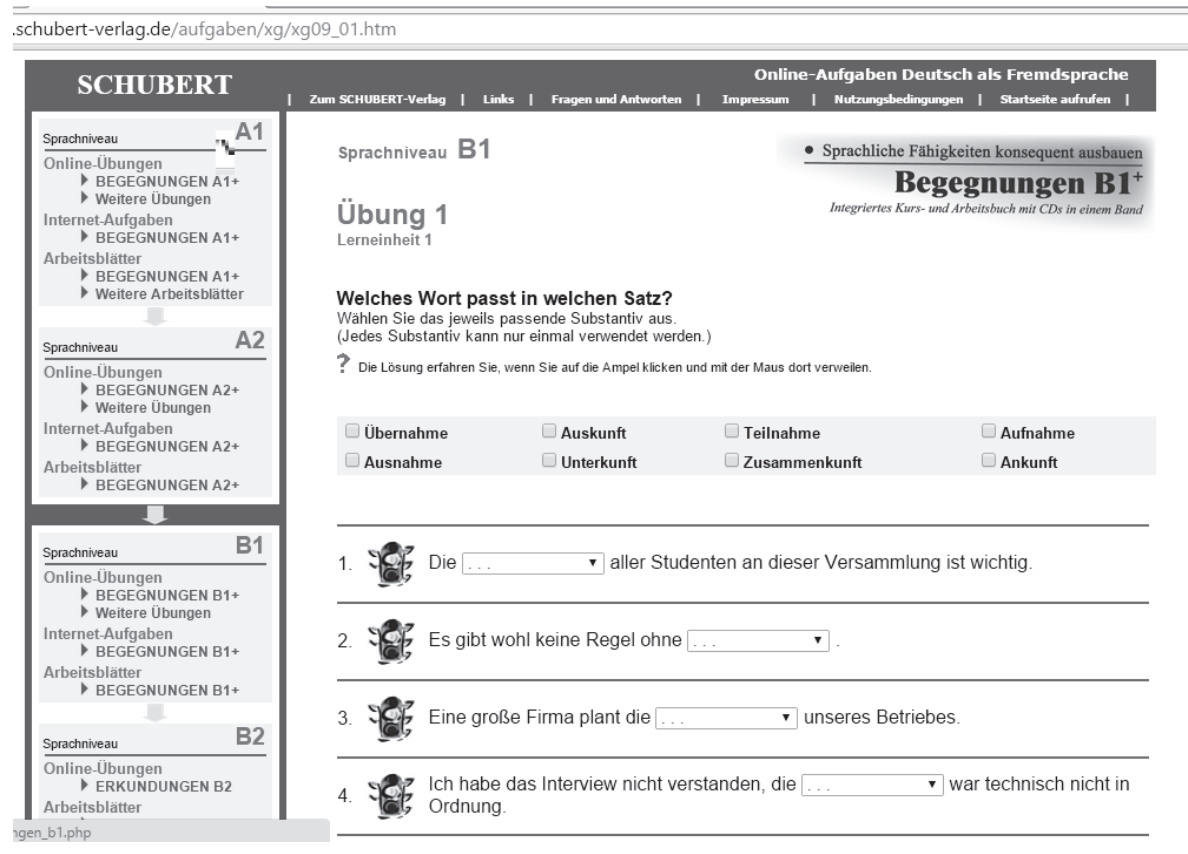

Forrás: http://www.schubert-verlag.de/aufgaben/xg/xg09_01.htm, 2015. május

Igaz ugyan, hogy ez utóbbi oldalt a kiadó tankönyvi leckéinek kiegészítésére hozta létre, de az adott tankönyvet nem használók is rengeteg gyakorlási lehetőséget kaphatnak itt.

Különösen hasznos, hogy a tankönyvet feldolgozók számára az online gyakorlás mellett (Online-Übungen) a leckék témáiban lehetőséget kínál egyéni vagy csoportos internetes kutatáshoz, projektmunkákhoz (Internet-Aufgaben).

A weboldalakon változatos, gyakran játékos feladatok gyakoroltatják az egyes idegen nyelvi készségeket, pl.:
- feleletválasztós feladat

- összekötősdi

- keresztrejtvény

- akasztófa-szókitaláló játékok

- lyukas szöveg

- szavak keverve

- mi a sorrend?

- szólánc

- kakukktojás

- memóriakártyák

- igaz-hamis

- hibakereső

- szó- vagy mondatpuzzle. 


\section{8. ábra szólás-puzzle}

www.iik.de/sites/default/files//spiele/puzzle/puzzle5.htm

\section{Sprüche - Puzzle 5}

Was steht hier geschrieben.

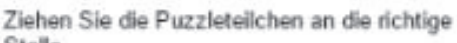
Stelle

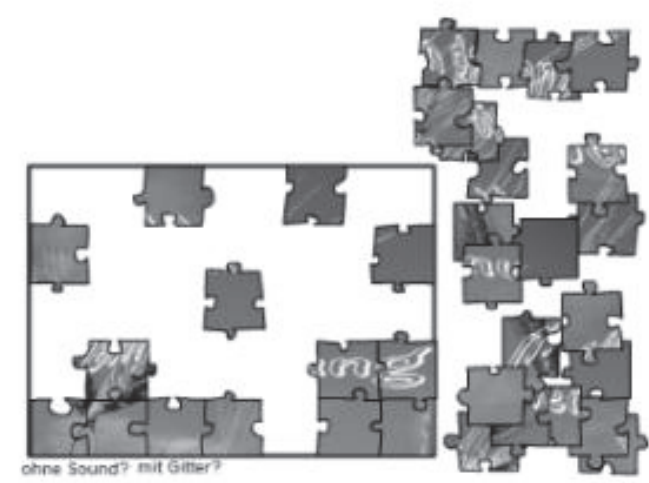

Deses Purzic entatand mit Unteratitsung van WwW. uhustein. de

Forrás: http://www.iik.de/sites/default/files//spiele/puzzle/puzzle5.html, 2015. március

9. ábra. hibakereső

C A [? www.iik.de/sites/default/files/spiele/brief1neu.html

Aus Fehlern lernen 1

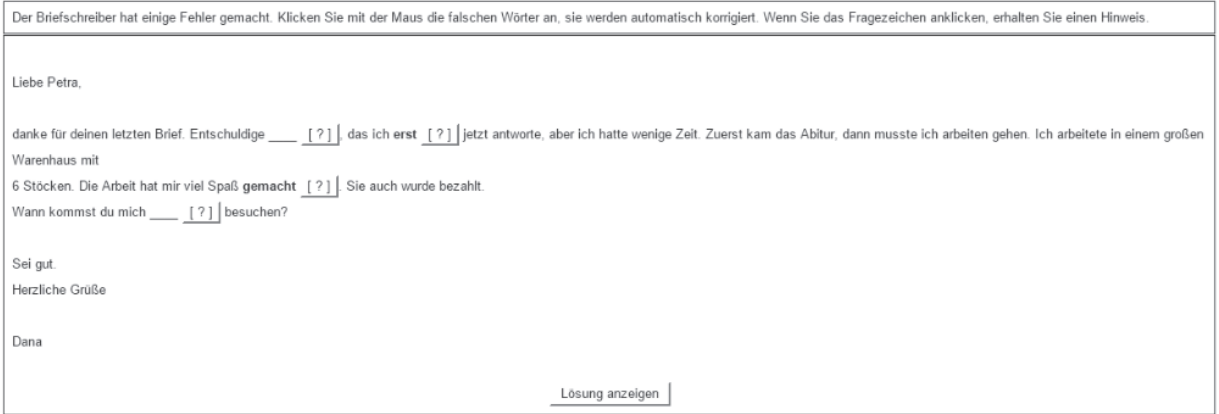

Forrás: http://www.iik.de/sites/default/files//spiele/brief1neu.html, 2015.május

A világháló sok lehetőséget kínál, hogy az újonnan szerzett idegen nyelvi készségeket begyakoroljuk és alkalmazzuk (pl. interaktív nyelvtani online-feladatok, didaktizált anyagok a hallás- és olvasásértés gyakorlására, oktatóvideók, kooperatív írásfeladatok, linkutalások egyes tankönyvekhez).
Az oktatás és a továbbképzések során azonban kiderül, hogy egy idegen nyelv effektív elsajátításának, ill. közvetítésének internetes (didaktizált vagy autentikus) anyagok segítségével történő lehetőségei még mindig nincsenek eléggé kihasználva - sem a nyelvtanulók, sem a tanárok részéről. 
Sok a bizonytalanság, hogy ezek az anyagok, hogyan integrálhatók az oktatás-tanulás folyamatába (Meister, H.; Shalaby, D., 2014: 7). Meggyőződésem: ettől függetlenül a nyelvtanulás könnyebbé, sikeresebbé, élvezhetőbbé tétele miatt a nyelvoktatásban használata indokolt.

\section{ÖSSZEGZÉS}

A modern technika adta lehetőséget a nyelvtanulás-tanítás folyamatában nem szabad mellőzni. A mai generáció a számítógépes világban nőtt fel, szívesen használja, kedveli a mindennapok során, a nyelvtanulásba is változatosságot hoz, ami pozitív kihatással lehet az eredményességre, fejleszti a kreativitást, az önbizalmat, az önértékelést. Nekem - mint a tanítás-tanulás szervezőjének és olyan nyelvtanárnak, aki évtizedek óta tanít - az volt a tapasztalatom, hogy a számítógép segítségével aktívabbak a hallgatók, érdeklődőbbek, szívesebben dolgoznak, mint a hagyományos tanítási módszerrel. Az online feladatok órán történő megoldásánál-ellenőrzésénél sikerélményt éreztem megnyilvánulásaikból, ez néha a vélemények egymás közötti ütköztetésében is megnyilvánult.

\title{
FELHASZNÁLT IRODALOM
}

[1.] Arnold, P.; Kilian, L.; Thilloson, A.; Zimmer, G. (2011): Handbuch E-Learning - Lehren und Lernen mit digitalen Medien. Bielefeld. Bertelsmann.

[2.] Meister, H.; Shalaby, D. (2014): E-Learning Handbuch für den Fremdsprachenunterricht. München. Hueber Verlag GmbH \& Co. KG.

[3.] Schlemminger, G. (2012): Virtuelle Welten - Serious Games im Fremdsprachenunterricht. online: http://www.goethe.de//hr/pri/d30/dos/dig/de9538543.htm, 2012, június.

\author{
https://card2brain.ch/ \\ http://comiclife.com/ \\ https://etherpad.mozilla.org/ \\ https://login.ubuntu.com \\ http://storybird.com/ \\ https://quizlet.com/ \\ https://www.dropbox.com/ \\ https://www.goethe.de \\ http://www.cobocards.com/de/ \\ http://www.eveil-3d.eu/index.php \\ http://www.iik.de/sites/default/files//spiele/brief1neu.html \\ http://www.iik.de/sites/default/files//spiele/puzzle/puzzle5.html \\ http://www.memocard.de/ \\ http://www.schubert-verlag.de/aufgaben/xg/xg09 01.htm \\ http://www.sulinet.hu/iktmuhely 2008/web2.html \\ http://www.wirtschaftsdeutsch.de/lehrmaterialien/telefon3.html
}


